\title{
Environmental and economic aspects of higher RES penetration into Macedonian power system
}

\author{
Boris Ćosić $^{\mathrm{a}, *, 1}$, Natasa Markovska ${ }^{\mathrm{b}}$, Goran Krajačića ${ }^{\mathrm{a}}$, Verica Taseska ${ }^{\mathrm{b}}$, Neven Duić $^{\mathrm{a}, 2}$

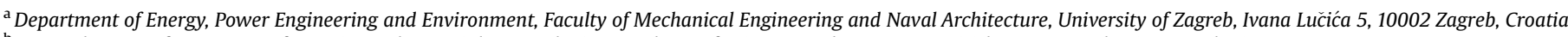 \\ ${ }^{\mathrm{b}}$ Research Center for Energy, Informatics and Materials, Macedonian Academy of Sciences and Arts, Krste Misirkov 2, 1000 Skopje, Macedonia
}

\section{A R T I C L E I N F O}

\section{Article history:}

Received 16 August 2011

Accepted 19 October 2011

Available online 29 October 2011

\section{Keywords}

Renewable energy

$\mathrm{CO}_{2}$ emissions

Energy system analyses

EnergyPLAN model

Macedonian energy system

\begin{abstract}
A B S T R A C T
The energy sector in Macedonia is the main emitter of greenhouses gases (GHG) with share of about 70\% in the total annual emissions. Furthermore, within the energy sector, $70-75 \%$ of emissions are associated with the electricity generation due to the predominant role of the lignite fuelled power plants. This makes the electricity sector the most significant key source and, at the same time, the main target for $\mathrm{CO}_{2}$ emissions reduction. Recently, the government has adopted a strategy for the use of RES which identifies a target of $21 \%$ of final energy consumption from RES by 2020 . The main goal of this paper is to investigate environmental and economic aspects of higher penetration of renewables into energy system of Macedonia. For this purpose a reference energy scenario for the power system expansion is developed by making use of EnergyPLAN model. The reference energy system was developed for the year 2020, and then used in the scenario analyses. The analyses of four 'RES' scenarios reveal that renewables can reduce $\mathrm{CO}_{2}$ emissions between $0.84 \%$ and $9.54 \%$ compared to reference scenario. Increase of $\mathrm{CO}_{2}$ price for double, compared to today's price, will lead to increase of annual operating costs over $26 \%$ in all the scenarios considered. In the case of doubling the lignite price, annual operating costs in scenarios will be increased between $6.5 \%$ and $7.6 \%$.
\end{abstract}

(c) 2011 Elsevier Ltd. All rights reserved.

\section{Introduction}

At the moment the most critical issues in European energy sector are security of supply and greenhouse gas emissions. These emissions are closely related to energy generation and exploitation and because of this they're becoming one of the major technological and socio-political challenges in the world [1]. One of the most promising solutions for alleviation of energy import and diversification of the energy resources, which at the same time reduce the GHG emissions, are renewable energy sources. Besides that, the utilisation of RES provides for additional environmental benefits (mitigating local pollution), create employment and leads to potential development of rural economies Unfortunately, the intermittent nature of renewable energy sources (RES), except biomass, leads to substantial RES penetration limits, especially during the period of low electricity consumption such as the night time [2] and [3]. To solve such a problem, effective tools are needed

\footnotetext{
* Corresponding author. Tel.: +385 1616 8242; fax: + 38516156940 .

E-mail addresses: boris.cosic@fsb.hr (B. Ćosić), natasa@manu.edu.mk (N. Markovska), goran.krajacic@fsb.hr (G. Krajačić), verica@manu.edu.mk (V. Taseska), neven.duic@fsb.hr (N. Duić).

1 http://www.powerlab.fsb.hr/bcosic.

2 http://www.powerlab.fsb.hr/neven.
}

to provide insights into the problem and to provide possible solutions [4].

In order to increase penetration limits of intermittent or variable RES and use them effectively it is necessary to increase flexibility of the power system. Flexibility can be increased by use of more dispatchable plants, by better interconnection with other power systems, by demand side measures and by energy storage [5]. This energy storage is used in order to transfer energy surplus from the period of excess electricity production to other more appropriate periods [6] and [7]. However, due to high investment cost in the storage systems the usage of RES is becoming even more expensive [8] and [9].

Many authors have evaluated and analyzed the benefits of integration RES and energy storage in terms of reduction $\mathrm{CO}_{2}$ emissions and energy import dependency. The use of RES-pumped hydro storage systems is proposed in [10], RES-hydrogen systems in [11] and use of RES-heat pumps and thermal storage systems in [12].

In the case of Macedonia, electricity production is based mainly on the low-quality domestic lignite and hydro. Macedonia's electricity consumption is characterised by excessive demand peaks in winter, which are largely due to the use of electricity heating to supplement fuelwood heating in the residential sector during very cold periods [13]. To some years ago, due to stagnation in the 
industry, particularly in heavy, energy-intensive industry, the country was able to generate all the electricity to be self sufficient but, in recent years, the increasing electricity demand has been covered by import, and during the last few years the import of electricity has grown rapidly [14] and [15]. Having this in mind, it is necessary to reduce the energy import dependency and GHG emissions by improving the energy efficiency and increasing the energy production from RES [16] and [17].

The main goal of this paper is to investigate environmental and economic aspects of higher penetration of RES into power system of Macedonia. As a first step, a reference model of the power system for the year 2020 has been developed by expansion of the reference model for the year 2008, generated in our previous study [18]. Then, comparative analyses are conducted for high penetration of RES in four 'RES' scenarios defined in line with the Macedonian strategy for RES [19]. The environmental aspects are considered through the potential of 'RES' scenarios for reduction of $\mathrm{CO}_{2}$ emissions, while the economy aspects are addressed analysing the sensitivity of 'RES' scenarios to the future lignite price and $\mathrm{CO}_{2}$ price.

\section{Methodology}

To create a model of the Macedonian energy system and to conduct environmental and economic analysis for higher RES penetration into power system of Macedonia, EnergyPLAN model [20] has been used. The main purpose of the model is to assist the design of national energy planning strategies on the basis of technical and economic analyses of the consequences of different national energy systems and investments [21]. The EnergyPLAN is an input/output model which incorporates heat and electricity supplies as well as the transport, individual and industrial sectors [22]. The input of the energy system consists of the following:

- Energy demands

- Energy production units and resources

- Regulation

- Costs

General inputs for these four groups are electricity and heat demand, energy station capacities, fuel consumption in energy stations, capacity of renewables stations, fuel consumption in individual buildings, industry and transport, fuel and $\mathrm{CO}_{2}$ costs, operation and investment cost of energy station capacities and different regulation strategies. Outputs are fuel consumption, import/export of electricity, $\mathrm{CO}_{2}$ emissions and the total cost of the energy system [22].

The EnergyPLAN model has already been used for the scenario analysis of energy systems with a high share of the intermittent sources as well as for the socio-economic feasibility studies. Hence, it has been applied to analyse energy systems with a high percentage of combined heat and power (CHP) and wind power [23], large scale integration of fluctuating renewable energy sources into the electricity system [24], socio-economic feasibility studies for $100 \%$ renewable energy systems [25], as well as in the analysis of $100 \%$ renewable energy systems of Croatia [9], Denmark [26] and Ireland [27].

Furthermore, the model can be used for technical analysis, market exchange analysis and feasibility studies. Technical analysis is used for large and complex energy systems at the national, local or regional level where different technical regulation strategies can be applied. In the case of the market exchange analysis each plant optimises according to businesses-economic profits, including any taxes and $\mathrm{CO}_{2}$ emissions costs [21]. For these analyses technical regulation and market-economic regulation can be used. The technical regulation minimise the import/export of electricity and seeks to identify the least fuel-consuming solution [21]. In this paper, balancing both heat and electricity demands, has been used as a technical regulation strategy. In this strategy, electricity production from the CHP units follows the production of heat. Basically, the decrease in heat production from CHP leads to decrease in electricity production from CHP. Hence, the CHP plants during the winter follow heat production while, during the summer period, when the heat demand is very low, CHP plants are working as a condensing plant. Furthermore, in the analyses of the Macedonian energy sector in [18], EnergyPLAN model and technical regulation strategy has been used.

\section{Planning of the Macedonian energy system}

\subsection{Reference energy system}

Energy system of Macedonia for 2020 has been reconstructed in EnergyPLAN model (2020 reference scenario) expanding the 2008 reference scenario from [18]. Reference scenarios 2008 and 2020 were constructed according to the scenario with energy efficiency measures from the Macedonian Strategy for Energy Development, which takes into account the already implemented measures for energy efficiency, the obligation to raise the electricity price to the market price until 2015, as well as realisation of the measures stipulated in the National Energy Efficiency Action Plan for energy savings in the amount of $33 \%$ of the target for 2020 [16]. According to that scenario, the total electricity consumption in the 2006-2020 period will increase by $41 \%$, while in the industry by $58.7 \%$ and by $27 \%$ in the residential sector. Furthermore, the results obtained in [18], show that EnergyPLAN model gives a high level of accuracy and that reference system could be used in the future analyses of the Macedonian power sector.

Table 1 provides the basic parameters of the lignite and hydro power plants in Macedonia. The total installed capacity of thermal power plants fuelled by lignite is $800 \mathrm{MW}$ while the installed capacity of hydro power plants is $580 \mathrm{MW}$, with a maximal annual production of around $7900 \mathrm{GWh}$ [14]. Data for hourly production of wind farms was calculated by making use of hourly wind speed provided by METEONORM program [28]. Hourly production data for hydro power plants have been obtained from [29] for year 2009 while hourly load data for Macedonian power system have been provided by [30]. Load curve for hourly district heating demand has been calculated by using degree-day and temperature obtained from METEONORM program [28].

Table 1

Basic parameters of power plants in Macedonia [16].

\begin{tabular}{lllll}
\hline $\begin{array}{l}\text { Name of } \\
\text { power plant }\end{array}$ & $\begin{array}{l}\text { Number of } \\
\text { aggregates }\end{array}$ & $\begin{array}{l}\text { Installed } \\
\text { power [MW] }\end{array}$ & $\begin{array}{l}\text { Commissioning } \\
\text { in system [year] }\end{array}$ & $\begin{array}{l}\text { Type of } \\
\text { power plant }\end{array}$ \\
\hline Bitola & 3 & 675 & $1982 / 1984 / 1988$ & Thermal PP \\
Oslomej & 1 & 125 & 1979 & Thermal PP \\
Vrutok & 4 & 172 & $1957 / 1973$ & Hydro PP \\
Tikvesh & 4 & 116 & $1966 / 1981$ & Hydro PP \\
Globochica & 2 & 42 & 1965 & Hydro PP \\
Shpilje & 3 & 84 & 1969 & Hydro PP \\
Kozjak & 2 & 80 & 2004 & Hydro PP \\
Raven & 3 & 21.6 & $1959 / 1973$ & Hydro PP \\
Vrben & 2 & 12.8 & 1959 & Hydro PP \\
MAK ROT & - & 37 & - & Hydro PP \\
$\quad$ Program & & & - & Hydro PP \\
Other EVN & - & 8 & - & Hydro PP \\
Other & - & 4.6 & - & - \\
$\quad$ companies & & 1380 & & \\
Total & - & & & \\
\hline
\end{tabular}


Table 2

Fuel prices and $\mathrm{CO}_{2}$ content in the fuels used in the calculation [16] and [32].

\begin{tabular}{cllllllll}
\hline & $\begin{array}{l}\text { Crude } \\
\text { oil }\end{array}$ & $\begin{array}{l}\text { Fuel } \\
\text { oil }\end{array}$ & Diesel & Petrol & $\begin{array}{l}\text { Coal } \\
\text { (lignite) }\end{array}$ & N gas & LPG & Biomass \\
\hline $\begin{array}{c}\text { Fuel prices } \\
{[€ / \mathrm{GJ}]}\end{array}$ & 17.97 & 12.93 & 17.78 & 19.50 & 1.76 & 10.18 & 11.27 & 3.26 \\
$\begin{array}{c}\mathrm{CO}_{2} \text { content } \\
\text { in fuel }\end{array}$ & - & 74 & 74 & 74 & 101.2 & 56.7 & 66.7 & - \\
$\quad[\mathrm{kg} / \mathrm{GJ}]$ & & & & & & & & \\
\hline
\end{tabular}

Macedonian electricity demand and fuel consumption used for reference energy system in 2020 was constituted by data obtained from [16]. Macedonian electricity demand is expected to rise from 8.64 TWh in 2008 to 10.05 TWh in 2020 equal to an annual rise of $2.5 \%$ [16]. Also, expected annual rise of energy demand in the industrial, residential, commercial and service, agriculture and forestry and transport sector, as determined in [16], have been included in the 2020 reference scenario.

Furthermore, investment costs for new energy units and price of fuel in the year 2020 have been obtained from [31] and from Strategic Energy Technology Information System (SETIS) web calculator [32]. In order to identified the price of fuel oil, diesel and petrol in the year 2020, assumption of the $150 \$ / \mathrm{bbl}(110 € / \mathrm{bbl})$ for the crude oil price was used [32]. The fuel price of fuel oil, diesel and petrol were calculated by using the price ratio between crude oil and these fuels as well as lower heating value of crude oil. The following ratios were used to calculate these prices [27]: ratio of crude oil to fuel oil was 0.71 , crude oil to diesel was 1 , and crude oil to petrol was 1.09. The fuel prices and $\mathrm{CO}_{2}$ content in the fuels used in the calculation are presented in Table 2.

\subsection{RES scenarios}

Analyses of Macedonian energy system in 2020 were conducted for four different scenarios and closed energy system. Furthermore, it is assumed that at least $30 \%$ of the power at any hour must come from power units capable of supplying ancillary (central power plant, CHP and hydro power plant). Data for wind and PV electricity production in first two scenarios are obtained from [19]. The minimum capacity for the condensing power plant (PP) is set to $510 \mathrm{MW}$ in all scenarios. The analyses of the hourly production of the condensing PP have shown that the minimum capacity is $510 \mathrm{MW}$, which is assumed in all 'RES' scenarios.

The first scenario, 'RES1', considers production of electricity from wind and PV systems in accordance with the lowest share of RES in the Strategy for utilisation of RES in Macedonia by 2020 [19]. Wind production of electricity is set to $180 \mathrm{GWh}(1.79 \%$ of total electricity demand in 2020) while the PV production of electricity is set to 14 GWh $(0.14 \%$ of total electricity demand in 2020$)$. All other data were maintained as in reference energy system.

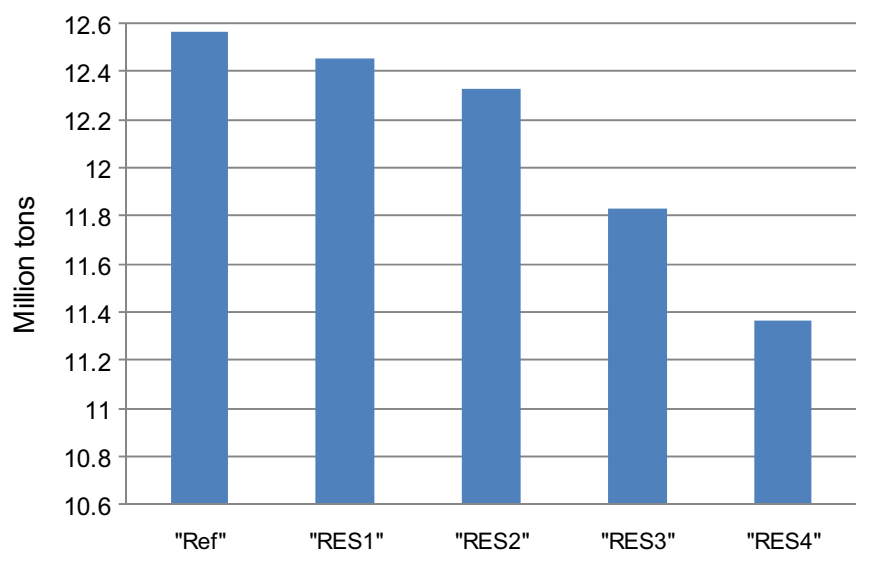

Fig. 1. $\mathrm{CO}_{2}$ emissions in the year 2020 for various scenarios.

The second scenario, 'RES2', considers production of electricity from wind and PV systems in accordance with the highest share of RES in the Strategy for utilisation of RES in Macedonia by 2020 [19]. Wind production of electricity is set to 360 GWh $(3.58 \%$ of total electricity demand in 2020) while the PV production of electricity is set to $42 \mathrm{GWh}(0.41 \%$ of total electricity demand in 2020). All other data were maintained as in reference energy system.

The third scenario, 'RES3', considers installations of all power plants from previous scenarios with the additional installation of one pump hydro storage (PHS) power plant. Assumptions for the 'RES3' scenario are:

- The electricity and heat demands are maintained at the same level as in the reference scenario.

- Production of electricity from PV is set to $0.5 \%$ of total electricity demand in 2020.

- Production of wind electricity is set to $10 \%$ of total electricity demand in 2020.

- New pumped hydro storage (PHS) power plant has been included. This PHS plant has a pump with capacity of 347.3 MW and a turbine with capacity of $332.8 \mathrm{MW}$.

The forth scenario, 'RES4', is scenario with the highest share of electricity produced from RES. Assumptions for the 'RES4' scenario are:

- The electricity and heat demands are maintained at the same level as in the reference scenario.

- Production of electricity from PV is set at $1 \%$ of total electricity demand in 2020.

- Production of wind electricity is set at $15 \%$ of total electricity demand in 2020.

Table 3

Installed components in the reference and the four 'RES' scenarios.

\begin{tabular}{|c|c|c|c|c|c|c|}
\hline \multirow[b]{2}{*}{ Scenarios } & \multicolumn{6}{|c|}{ Installed components in the scenarios } \\
\hline & $\begin{array}{l}\text { Thermal power } \\
\text { plant [MW] }\end{array}$ & $\begin{array}{l}\text { Pump hydro } \\
\text { storage [MW] }\end{array}$ & $\begin{array}{l}\text { Wind production } \\
\text { [\% of total consumption] }\end{array}$ & $\begin{array}{l}\text { PV production } \\
\text { [\% of total consumption] }\end{array}$ & $\begin{array}{l}\text { Gas fired } \\
\text { CHP [MW] }\end{array}$ & $\begin{array}{l}\text { Power plant } \\
\text { Minimum [MW] }\end{array}$ \\
\hline 'Ref' & 800 & - & - & - & 227 & 510 \\
\hline 'RES1' & 800 & - & 1.79 & 0.14 & 227 & 510 \\
\hline ‘RES2’ & 800 & - & 3.58 & 0.41 & 227 & 510 \\
\hline ‘RES3’ & 800 & $332.8 / 347.3$ & 10 & 0.5 & 227 & 510 \\
\hline ‘RES4’ & 800 & $332.8 / 347.3$ & 15 & 1 & 227 & 510 \\
\hline
\end{tabular}




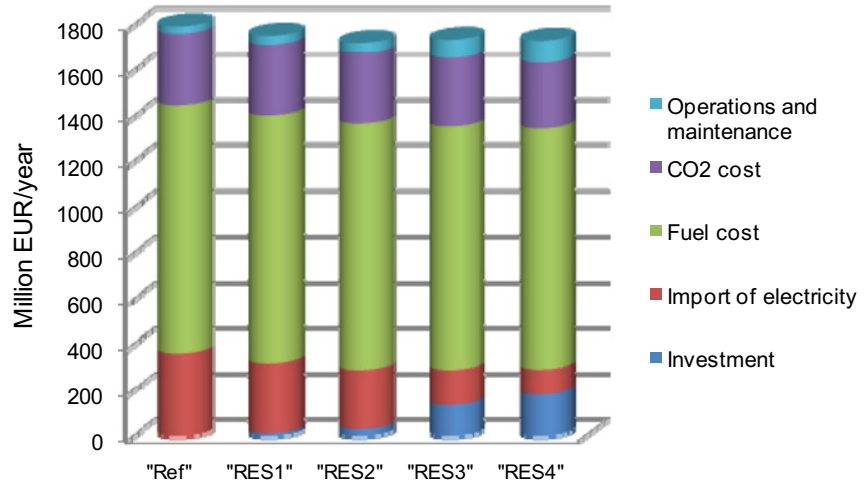

Fig. 2. Annual operating cost of the various scenarios.

Detailed description of installed components in four 'RES' scenarios as well as in reference scenario are given in Table 3.

\section{Results}

\subsection{Environmental evaluation of 'RES' scenarios}

The $\mathrm{CO}_{2}$ content in the fuels from Table 1 have been used in order to calculate $\mathrm{CO}_{2}$ emissions associated to each of the scenarios (Fig. 1.).

Results have shown that in the year 2020, decrease of $\mathrm{CO}_{2}$ emissions in the 'RES1' scenario is $0.84 \%$ while in the 'RES4' scenario $\mathrm{CO}_{2}$ emissions are lower for $9.54 \%$ compared to reference scenario.

\subsection{Economic evaluation of 'RES' scenarios}

This section evaluates the impact of $\mathrm{CO}_{2}$ price and lignite price on Macedonian energy system including sensitivity analyses to these parameters of the 'Ref' and the 'RES' scenarios. The first step is to calculate annual operating cost of 'RES' scenarios. For this calculation, fuel prices from Table 2 and $\mathrm{CO}_{2}$ price of $25 € / t$ [33] have been used. Operating costs of the condensing lignite fired power plants in Macedonia were obtained from [16]. The total operating and maintaining (O\&M) costs of lignite fired power plant in Macedonia are $7.7 € / \mathrm{MWh}$. The onshore wind and PV costs were obtained from a report completed by the Danish Energy Authority [31]: investment costs for onshore wind are $1.5 \mathrm{M} € / \mathrm{MW}$ and $\mathrm{PV}$ is $4 \mathrm{M} € / \mathrm{MW}$. Fixed O\&M costs for onshore wind are $12 € / \mathrm{MWh}$ while the total O\&M costs of PV are $20 € /$ MWh. Total annual operating cost of 'RES' scenarios are presented in Fig. 2 and Table 4.

Results presented in Fig. 2 have shown that the fuel price has the highest impact on economy. Also, $\mathrm{CO}_{2}$ costs have a large share in total costs and these penalties are even higher than annual investment costs in RES technologies.

Table 4

Annual operating costs in the reference and four RES scenarios.

\begin{tabular}{lrrrrr}
\hline Costs in million EUR & 'Ref & 'RES1' & 'RES2' & 'RES3' & 'RES4' \\
\hline Investment & 0 & 14 & 33 & 137 & 183 \\
Import of electricity & 364 & 308 & 259 & 155 & 111 \\
Fuel cost & 1086 & 1084 & 1080 & 1068 & 1057 \\
CO2 cost & 314 & 311 & 308 & 296 & 284 \\
Operations and maintenance & 32 & 38 & 44 & 82 & 99 \\
Total costs & 1796 & 1755 & 1724 & 1738 & 1734 \\
\hline
\end{tabular}

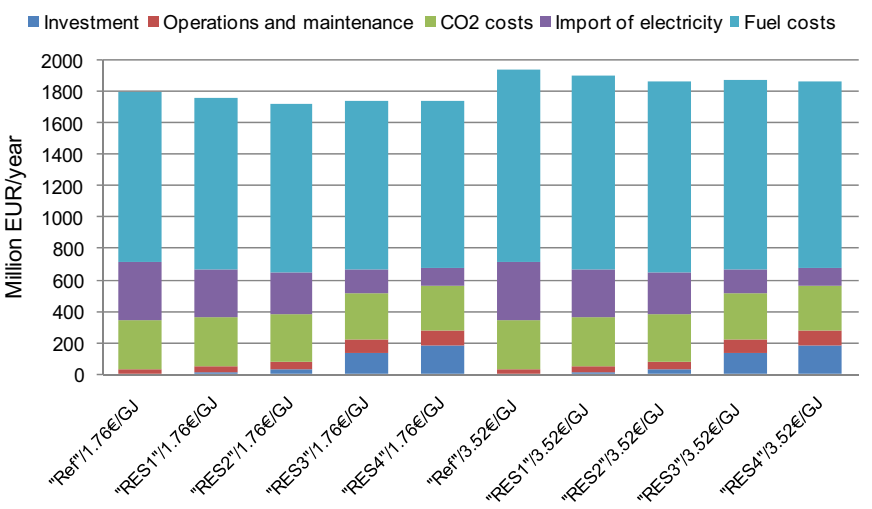

Fig. 3. Annual operating cost of 'RES' scenarios for lignite price of $31 € / t$.

Furthermore, the annual operating costs were also calculated for higher coal and $\mathrm{CO}_{2}$ prices as they are expected to be in the future. The case of doubling these prices is analyzed (coal price of $3.52 € \mid$ $\mathrm{GJ}$, lignite price in Macedonian conditions $31 € / \mathrm{t} ; \mathrm{CO}_{2}$ price $50 € / \mathrm{t}$ ) and the results of this sensitivity analyses have been presented in Fig. 3 and Fig. 4.

Obviously (Fig. 3) the increase of lignite price will have a low impact on the total annual operating costs, but a very high impact on the operating costs of power plants fuelled by lignite. Doubled, the lignite price will lead to increase of total annual operation costs in 'RES4' scenario for $6.8 \%$ and for $7.5 \%$ in the reference scenario. Comparing the two 'Ref' scenarios, the fuel costs of lignite fired power plants are higher for $146 \mathrm{M} €$ in the doubled lignite price 'Ref' scenario. Furthermore, in doubled lignite price case, the annual operating costs of 'RES4' scenario are only $97 \mathrm{M} €$ higher than the ones of the 'Ref' scenario with current lignite price, and even lower for $49 \mathrm{M} €$ than the annual operating costs the 'Ref' scenario in doubled lignite price case.

Results of costs analysis, presented in Fig. 4, have indicated that increase of $\mathrm{CO}_{2}$ price will have huge impact on the annual energy costs in Macedonia. The increase of $\mathrm{CO}_{2}$ price from $25 € / \mathrm{t}$ to future price of $50 € / \mathrm{t}$ will lead to increase of annual operating costs over $26 \%$ in all the scenarios considered.

These results suggest that investments in regulation of the existing lignite fired power plants are needed in parallel with the measures for better utilisation of the les carbon intensive fuels. That will reduce the impact of the $\mathrm{CO}_{2}$ price on the electricity price, as well as on the total operating costs of the power plants.

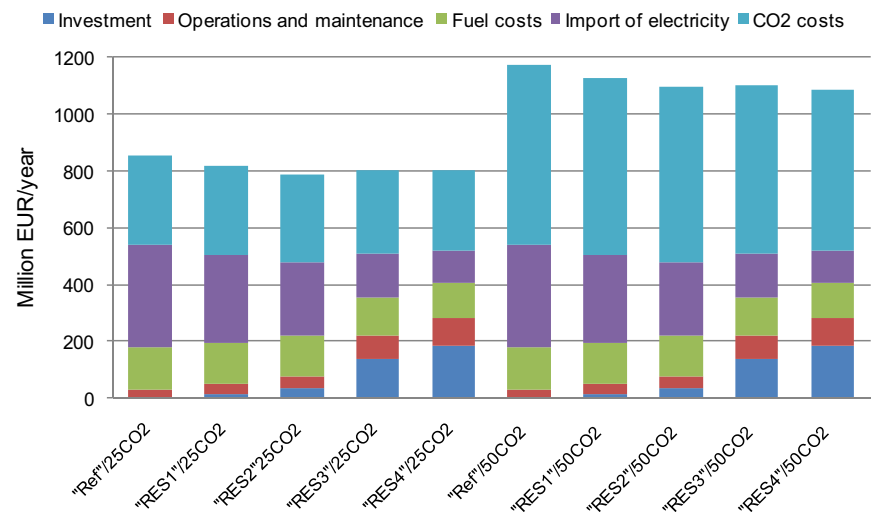

Fig. 4. Annual operating costs of 'RES' scenarios for $\mathrm{CO}_{2}$ price of $50 € / \mathrm{t}$. 


\section{Conclusion}

In this paper the energy system of Macedonia in the year 2020 is modelled and then used for scenario analyses of high penetration of renewables into existing energy system. The results of scenario analyses show that the $\mathrm{CO}_{2}$ emissions from the energy sector can be reduced from $0.84 \%$ in the 'RES1' scenario to $9.54 \%$ in the 'RES4' scenario.

The results of sensitivity analyses show that coal price and $\mathrm{CO}_{2}$ price have huge impacts on the economy of the energy system. In the case of increase of lignite price for double, annual operating costs in scenarios will be increased between $6.5 \%$ and $7.6 \%$. Doubling the $\mathrm{CO}_{2}$ price will lead to increase in the annual operating costs of over $26 \%$ in all scenarios. Furthermore, analyses show that the total electricity needs cannot be covered by own production and further investment in the generation capacities is indispensable. Also, the increased penetration of RES would require investments in the regulation system of the existing lignite fired power plants.

\section{References}

[1] J. Klemeš, P. Stehlik, Heat integration, energy management, $\mathrm{CO}_{2}$ capture and heat transfer enhancement, Applied Thermal Engineering 27 (16) (2007) 2627-2632.

[2] J.K. Kaldellis, Maximum wind energy contribution in autonomous electrical grids based on thermal power stations, Applied Thermal Engineering 27 (8-9) (2007) 1565-1573.

[3] B. Cosić, Z Stanić, N. Dui\&cacute, Geographic distribution of economic potential of agricultural and forest biomass residual for energy use: case study Croatia, Energy 36 (4) (2011) 2017-2028.

[4] F.X.X. Zhu, L. Vaideeswaran, Recent research development of process integration in analysis and optimisation of energy systems, Applied Thermal Engineering 20 (15-16) (2000) 1381-1392.

[5] International Energy Agency, in: Hugo Chandler (Ed.), Harnessing Variable Renewables - A Guide to the Balancing Challenge, IEA, Paris, France, 2011.

[6] G. Krajačić, N. Duić, B.V. Mathiesen, M.G. Carvalho, Smart energy storages for integration of renewables in $100 \%$ independent energy systems, Chemical Engineering Transactions 21 (2010) 391-396.

[7] G. Zini, P. Tartarini, Hybrid systems for solar hydrogen: a selection of casestudies, Applied Thermal Engineering 29 (13) (2009) 2585-2595.

[8] H. Lund, G. Salgi, B. Elmegaard, A.N. Andersen, Optimal operation strategies of compressed air energy storage (CAES) on electricity spot markets with fluctuating prices, Applied Thermal Engineering 29 (5-6) (2009) 799-806.

[9] G. Krajačić, N. Duić, Z. Zmijarević, B.V. Mathiesen, A. Anić Vučinić, M.G. Carvalho, Planning for a $100 \%$ independent energy system based on smart energy storage for integration of renewables and $\mathrm{CO}_{2}$ emissions, Applied Thermal Engineering 31 (13) (2011) 2073-2083.

[10] M. Kapsali, J.K. Kaldellis, Combining hydro and variable wind power generation by means of pumped-storage under economically viable terms, Applied Energy 87 (11) (2010) 3475-3485.

[11] R. Martins, G. Krajacic, L. Alves, N. Duic, T. Azevedo, M.D.G. Carvalho, Energy storage in islands - modelling Porto Santo's hydrogen system, Chemical Engineering Transactions 18 (2009) 367-372.
[12] N. Pardo, A. Montero, J. Martos, J.F. Urchueguia, Optimization of hybrid ground coupled and air source - heat pump systems in combination with thermal storage, Applied Thermal Engineering 30 (8-9) (2010) 1073-1077.

[13] IEA, Energy in the Western Balkans - The Path to Reform and Reconstruction. IEA Publications, Paris, France, 2008, ISBN 978-92-64-04218-6.

[14] V. Taseska, N. Markovska, A. Causevski, T. Bosevski, J. Pop-Jordanov, Greenhouse gases (GHG) emissions reduction in a power system predominantly based on lignite, Energy 36 (4) (2011) 2266-2270.

[15] N. Markovska, V. Taseska, J. Pop-Jordanov, SWOT, Analyses of the national energy sector for sustainable energy development, Energy 34 (6) (2009) 752-756.

[16] Ministry of Economy, Strategy for Energy Development in the Republic of Macedonia Until 2030 [Internet]. Skopje, Macedonia (2010) Available at www.economy.gov.mk/WBStorage/Files/Macedonian_Energy_Strategy_until_ 2030_adopted.pdf [accessed 17.10.11].

[17] N. Markovska, M. Todorovski, T. Bosevski, J. Pop-Jordanov, Cost and Environmental Effectiveness of Climate Change Mitigation Measures, Sustainable Energy Production and Consumption. Springer Science, 2008, 67-73.

[18] B. Ćosić, N. Markovska, V. Taseska, G. Krajačić, N. Dui\&cacute, The potential of GHG emission reduction in Macedonia by renewable electricity, Chemical Engineering Transactions 25 (2011) 57-62.

[19] Ministry of Economy, Strategy for Utilisation of Renewable Energy Sources in the Republic of Macedonia by 2020 [Internet]. Skopje, Macedonia Available at (2010). www.economy.gov.mk/WBStorage/Files/Strategy_for_utilizationa_ RES.pdf [accessed 17.10.11].

[20] EnergyPLAN, Advanced Energy System Analysis Computer Model [Internet] Aalborg University, Denmark. Available at: www.energy.plan.aau.dk/, (accessed 17.10.11).

[21] H. Lund, EnergyPLAN - Advanced Energy System Analysis Computer Model, Users Manual Documentation Version 9.0. Aalborg University, Aalborg, Denmark, 2011.

[22] D. Connolly, H. Lund, B.V. Mathiesen, M. Leahy, A review of computer tools for analysing the integration of renewable energy into various energy systems, Applied Energy 87 (4) (2010) 1059-1082.

[23] H. Lund, E. Münster, Modelling of energy systems with a high percentage of CHP and wind power, Renewable Energy 28 (14) (2003) 2179-2193.

[24] H. Lund, Large-scale integration of optimal combinations of PV, wind and wave power into the electricity supply, Renewable Energy 31 (4) (2006) 503-515.

[25] B.V. Mathiesen, H. Lund, K. Karlsson, $100 \%$ Renewable energy systems, climate mitigation and economic growth, Applied Energy 88 (2) (2011) 488-501.

[26] H. Lund, B.V. Mathiesen, Energy system analysis of $100 \%$ renewable energy systems-The case of Denmark in years 2030 and 2050, Energy 34 (5) (2009) 524-531.

[27] D. Connolly, H. Lund, B.V. Mathiesen, M. Leahy, The first step towards a $100 \%$ renewable energy-system for Ireland, Applied Energy 88 (2) (2011) 502-507.

[28] METEONORM, Global Meteorological Database for Engineers, Planners and Education [Internet]. Available at: www.meteonorm.com/pages/en/meteonorm. php, (accessed 17.10.11).

[29] MEPSO, Electricity Transmission System Operator of Macedonia [Internet] Available at: www.mepso.com.mk/en-us/ListanjeIzveshtai.aspx?categoryID= 138, (accessed 17.10.11).

[30] ENTSO-E, European Network of Transmission System Operators for Electricity [Internet]. Available at: www.entsoe.eu/db-query/country-packages/ production-consumption-exchange-package/, (accessed 17.10.11).

31] Technology Data for Energy Plants [Internet]. Danish Energy Agency, Copenhagen, Denmark, 2010, Available at. www.ens.dk/Documents/Netboghandel\% 20-\%20publikationer/2010/Technology_data_for_energy_plants.pdf [accessed $17.10 .11]$.

[32] SETIS Calculator [Internet], JRC, European Commission, Available at: https:// odin.jrc.ec.europa.eu/SETIS/SETIS1.html\# [accessed 17.10.2011].

[33] International Energy Agency, World Energy Outlook 2009. IEA, Paris, France, 2009, Available at. www.iea.org/textbase/nppdf/free/2009/WEO2009.pdf [accessed 17.10.11]. 